\title{
Biocycling of Fractional Fatty Acid Components of Lipids in Mangrove-Benthic Systems, in Midnapore (East) Coast, India
}

\author{
Samaresh samanta, Tapas das, Sudipta Ghorai and Susanta Kumar Chakraborty* \\ Department of Zoology, Vidyasagar University, India \\ *Corresponding author: Susanta Kumar Chakraborty, Professor of Zoology, Vidyasagar University, Midnapore-721102, West Bengal, India
}

Submission: 眥 September 12, 2017 ; Published: 眥 February 06, 2018

\begin{abstract}
Animals are important in nutrient cycling in mangrove-estuarine ecosystems by virtue of their foraging and excretory processes which convert complex organics into simpler ones (nitrogen, phosphorus etc) and thereby support a substantial proportion of the nutrient demands of primary producers. Different categories of good quality fatty acids are considered to be important determinants of health and stability of mangrove ecosystem as found from the present studies on the functional roles rendered by selected intertidal macro benthos at an ecotone (Talshari), the confluence of an estuary, Subarnarekha with an open sea, Bay of Bengal, near Midnapore (East), coast, West Bengal, India. These biochemical entities not only represent a major pool of nutrients but also throw light with regard to nutrient cycling among different compartments of coastal ecosystem (Plants, Animals Soil, and Water), especially through trophic interactions. Three different benthic fauna were selected from this studied eco-zone for detailed analysis of their lipids and essential fatty acids (EFAs) in respect of their association and dependence on mangrove plants and detritus rich soil. These EFAs after being entered within body of benthic fauna undergo biotransformation and bioconversion processes from different food sources available in plenty at this intertidal basin. Several saturated and unsaturated fatty acids present within the body of studied animals have indicated that these biochemical components can be considered as a good biomarker for understanding food chain and food web dynamics of a mangrove-estuarine ecosystem.
\end{abstract}

Keywords: Trophic interactions; Lipids; Fatty acids; Biomarker; Mangrove; Estuary and Benthic animals

\section{Introduction}

The cycling of nutrients is critical for the sustenance of ecosystems [1,2] which is meant as the transformation of nutrients from one trophic level to another, mainly done by microbes after being facilitated by several other faunal components in an mangrove estuarine ecosystem [3,4] Nutrient inputs from outside ecosystem (often referred to as allochthonous inputs) are also important in many ecosystems $[5,6]$. However, over the past three decades, ecologists have shown that animals can become instrumental in cycling of nutrients in terrestrial, marine, and freshwater ecosystems [7-9]. Intertidal benthic fauna render direct effects emanating from the physiological transformation of nutrients from one form to another within their own bodies by way of consumption and subsequent allocation of nutrients to feces, growth, and nutrient excretion. Indirect effects are supposed to occur when animals affect nutrient fluxes the process of harvesting their foods and modifying physical habitat structure by way of bioturbation process [4].

Coastal zone representing the junction of terrestrial with marine ecosystems, harbors diversified flora, fauna, and microbes in the form of mangroves and its associates, benthos (macro, micro and meio benthos), nekton and plankton in different geo- morphological units like estuaries, creeks, intertidal and sub-tidal zones, mangroves, delta etc as habitats and ecological niche. All these faunal and floral inhabitants have been found to display varied patterns of succession, distribution, and eco-dynamics in tune with the changing ecological gradients and also by enjoying definite ecological niche. Marine- coastal-estuarine-mangrove ecosystem representing the most productive and dynamic ecosystem of the world, is dominated by intertidal salt tolerant halophytic vegetation and enjoying the influences of two high and two low tides a day, offers a unique environment for bioresource development on one hand and maintains ecological balance through the protection of coastal line on the other [4,10-14]. Indian coast has a land frontier of $15,200 \mathrm{~km}$. Coast line stretches about $5700 \mathrm{~km}$ on the main land and about $7500 \mathrm{~km}$ including the two island territories and exhibits most of the known geo-morphological features of coastal zones. Presently Indian coastline is facing increasing human pressures which have resulted in substantial damage to its ecosystems [15]. The coastal area of West Bengal extends over 0.28 million hectors and 220KM of coastal line. The coastal belt of Midnapore district, West Bengal, India sharing 27\% (60KM) of coastal tract of West Bengal, India is a contiguous part of deltaic Sundarbans Mangrove Ecosystem-a world Heritage site [16]. 
In mangrove-estuarine-coastal ecosystem, the open pathways of nutrient transports are driven by physical processes, such as, tides, run off, meteorological parameters like precipitation and biological factors especially litter fall, decomposition and mineralization. The primary food source for aquatic and intertidal mangrove dwelling faunal components is derived from vascular plant detritus mostly from mangrove leaves. The breakdown of mangrove leaves is brought about by the activities of macrofauna (crabs, molluscs, insects etc) and microorganisms, such as, fungi, bacteria and protozoa $[17,18]$. Most of the intertidal benthic fauna of Midnapore (East) coastal region are deposit feeders or browsers or filter feeders. Trophic interactions in such ecosystems are often very complex, largely because of the interactions of an array of ecological parameters both living and non living components pertaining to both aquatic and adjoining forest subsystems [14,1922]. The use of lipid and its different fatty acid fractions have used as biomarkers to understand trophic relationships, especially the biotransformation and bioconversion of organic components through a pathway of plants to benthos to soil and microorganisms. In such aquatic-soil-forest subsystems, lipids provide the densest

\section{Material and Methods}

form of energy which is transferred from algae to vertebrates via zooplankton [23] and several essential fatty acids along with sterols have been found to be the important driver of ecosystem dynamics and sustainability by ensuring ecosystem stability [4,21,24 - 26].

In a marine ecosystem, generally qualitative similarities are observed in the fatty acid composition of the organisms although they occupy different trophic levels. The prime producer i.e. phytoplankton in estuarine-marine ecosystems are able to synthesize all the fatty acids de novo. Those fatty acids undergo significant changes in the process of decomposition of mangrove leaves, deposited and stored in the tidal basin from mangrove plants [19]. Through feeding upon detritus available on mudflats, these biotransformed fatty acids tend to enter within the body of macro benthic fauna enjoying a position on higher trophic level of this specialized ecosystem. In such context, the present paper has attempted to highlight the functional roles of three major benthic fauna-one fiddler crab Uca acuta acuta, one brachiopod-Lingula anatina and one nemertine-Cerebratulus bengalensis towards the conversion of lipid components and their bioconversion and biotransformation in this ecosystem on a comparative basis.

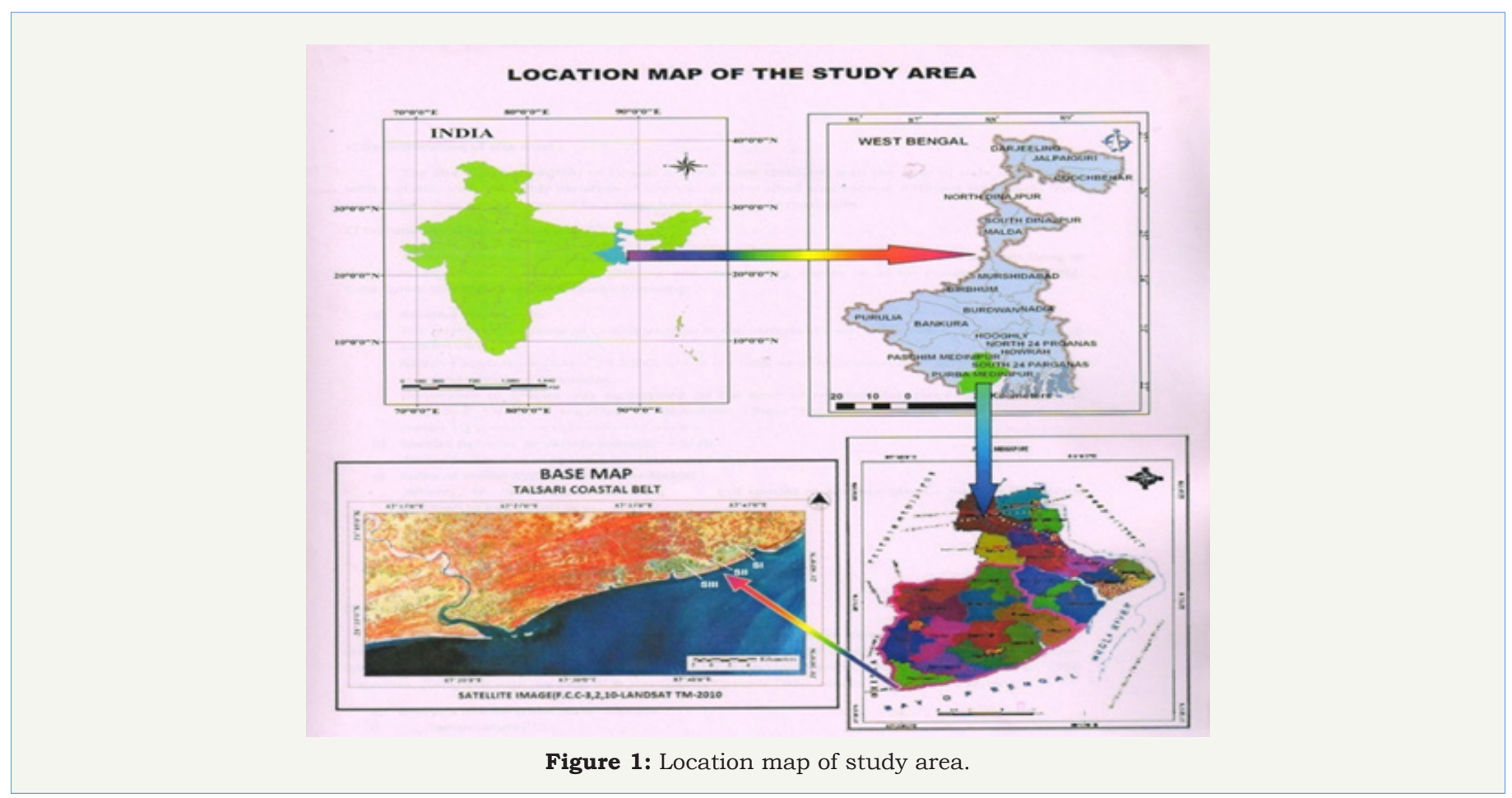

Individuals of three major macrobenthic fauna Lingula anatina (Brachiopod), Uca acuta acuta (Fiddler crab) and Cerebratulus bengalensis (Nemertine) were collected randomly from the intertidal mudflats of an ecotone (Talshari) ,located at the confluence of an estuary, Subarnarekha with open sea, Bay of Bengal (Longitude $87^{\circ} 5^{\prime} \mathrm{E}$ to $88^{\circ} 5^{\prime} \mathrm{E}$ and Latitude $20^{\circ} 30^{\prime} \mathrm{N}$ to $22^{\circ} 2^{\prime} \mathrm{N}$ ) near New Digha, West Bengal, India (Figure 1) along with the simultaneous collection of detritus and mangrove leaves from three major mangrove plants viz. Avicennia marina, Acanthus ilicifolius and Suaeda maritima. Both phytoplankton and zooplankton were collected by filtering
$100 \mathrm{~L}$ of water using plankton nets having a mesh size of $0.35 \mu$ and $0.50 \mu$ respectively. Different body parts of all three animals were separated by dissection in the laboratory. The plankton samples, detritus, plant leaves and different dissected body parts were immediately frozen and stored at $-20{ }^{\circ} \mathrm{C}$ until analyzed (Figure 2). The study was undertaken during pre-monsoon period 20142015. The collection, extraction, preparation estimation, and identification of total lipids and fractional components of fatty acids were done following the methods of [27-32] which are being mentioned below: 


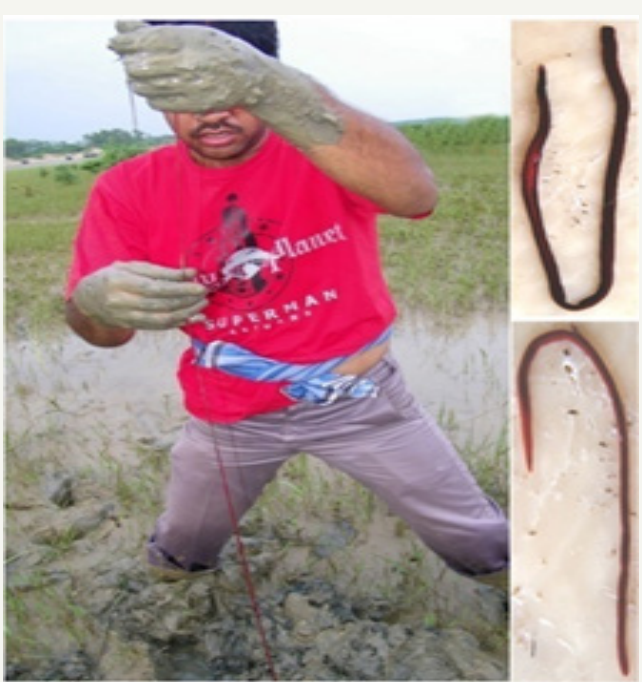

Figure 2: Cerebratulus bengalensis.

The total lipids were extracted from the flesh of the collected samples following the method of [27] using methanol-chloroform $(2: 1 \mathrm{v} / \mathrm{v})$, methanol-chloroform water $(2: 1: 0.8 \mathrm{v} / \mathrm{v} / \mathrm{v})$, and then again with the first solvent system. Samples were grounded with the solvent, filtered and residual components were extracted with the next solvent system. The process was repeated. Finally, the three extracts were pooled, diluted with water and layers generated were allowed to separate in separator funnels. The chloroform layer at the bottom was withdrawn and dried over anhydrous sodium sulphate in a freezer. The chloroform solution of lipid was evaporated under vacuum, redissolved in distilled n-hexane and kept at $-20{ }^{\circ} \mathrm{C}$ for future use. Butylated hydroxy toluene was added at a level of $100 \mathrm{mg} / \mathrm{L}$ to the solvent as antioxidant. After dilution of the pooled extracts, a heavy white precipitate appeared at the junction of the two layers which were saved for further analysis.

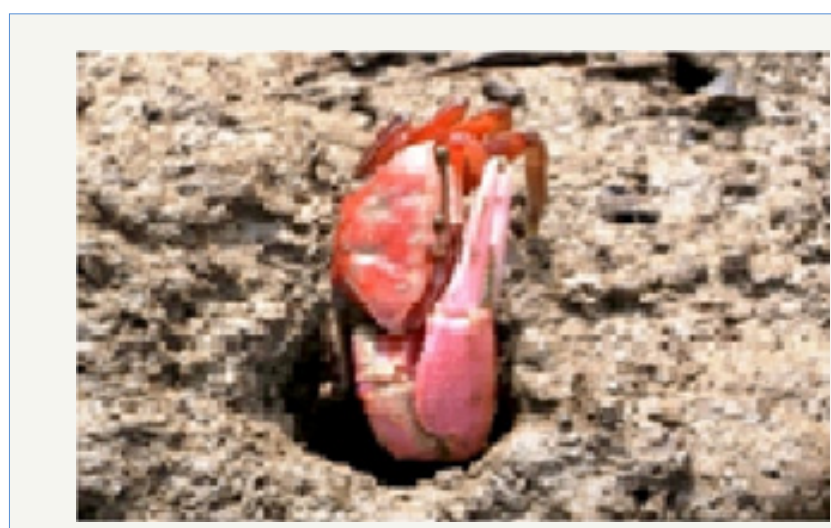

Figure 3: Uca acuta acuta.

A portion of total lipid samples were dissolved in anhydrous methanol containing concentrated sulfuric acid $(1 \%, v / v)$ and the mixture was refluxed for $2 \mathrm{~h}$. Methanol was evaporated to a small volume and cooled. Distilled water was added to the cooled mixture and the methyl esters of fatty acids were extracted three times with aliquots of diethyl ether (Figure 3). The ethereal extracts were pooled and driedover anhydrous sodium sulphate, filtered, vacuum dried, redissolved in n-hexane and kept for future use.

\section{Purification of fatty acid methyl esters by thin layer chromatography (TLC)}

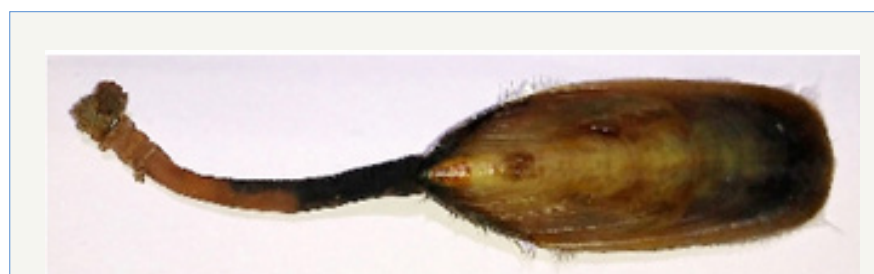

Figure 4: Lingula anatina.

Fatty acid methyl esters were purified by TLC using a solvent system of n-hexane diethyl ether (90:10, v/v). A standard methyl ester was also run on the same plate in a separate lane. The location of methyl ester bands were done by placing the TLC plate in an iodine vapour chamber (Figure 4). The methyl ester bands corresponding to the standard were marked and then scrapped off the plate. Methyl esters were recovered by extracting the bands in a mini column with chloroform, the later was evaporated and the methyl esters were then kept in $\mathrm{n}$-hexane till analyzed by gas liquid chromatography (GLC).

\section{Gas liquid chromatography}

GLC of fatty acid methyl esters were done on a Chemito 1000 instrument, equipped with flame ionization detector. Quantification was done by computer using specific Clarity Lite Software.

\section{Analysis of fatty acid methyl esters}

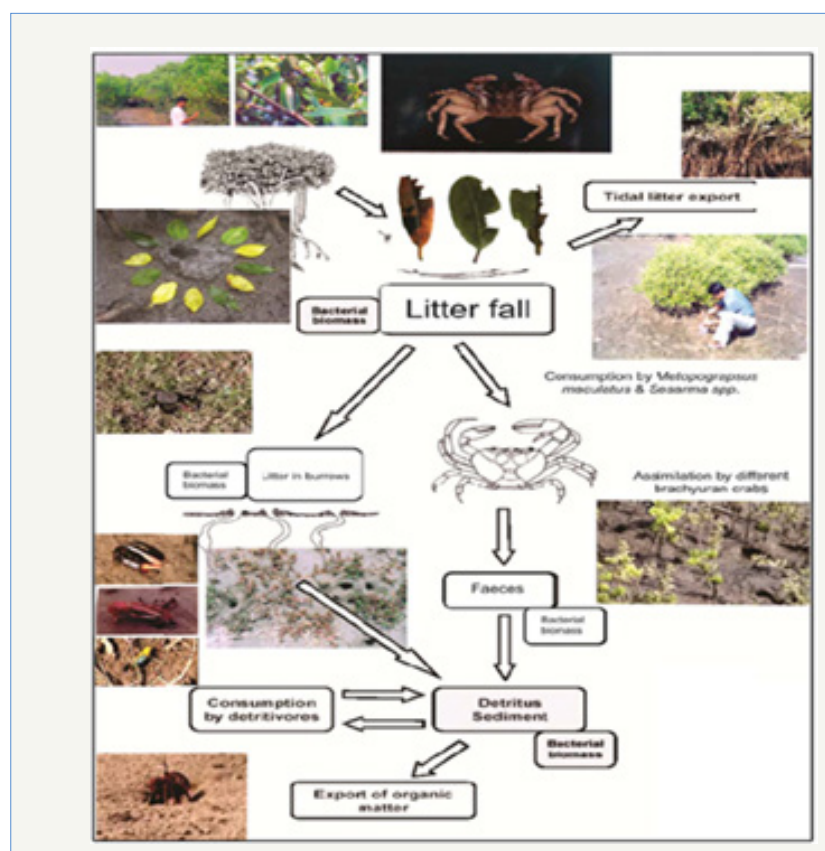

Figure 5: Litter decomposition by fiddler crab.

GLC of fatty acid methyl esters was done on a BPX-70 mega bore capillary column obtained from SGE, Australia. Oven temperature was programmed from $150-240^{\circ} \mathrm{C}$ with a rate of $8^{\circ} \mathrm{C} / \mathrm{min}$. Initial and final times were kept isothermal for $1 \mathrm{~min}$ and $20 \mathrm{~min}$, respectively. Injection port and detector temperatures were $250{ }^{\circ} \mathrm{C}$ and $300{ }^{\circ} \mathrm{C}$, respectively (Figure $5 \& 6$ ). Nitrogen gas was used as carrier gas and its flow rate was $6.32 \mathrm{ml} / \mathrm{min}$. Identification of fatty acids was 
done by comparing their retention times with those of standards, chromatographed under identical operational conditions of GLC. Conformations of fatty acids were made by using the fatty acid methyl ester of cod liver oil fatty acids reffered by Ackman RG [28].

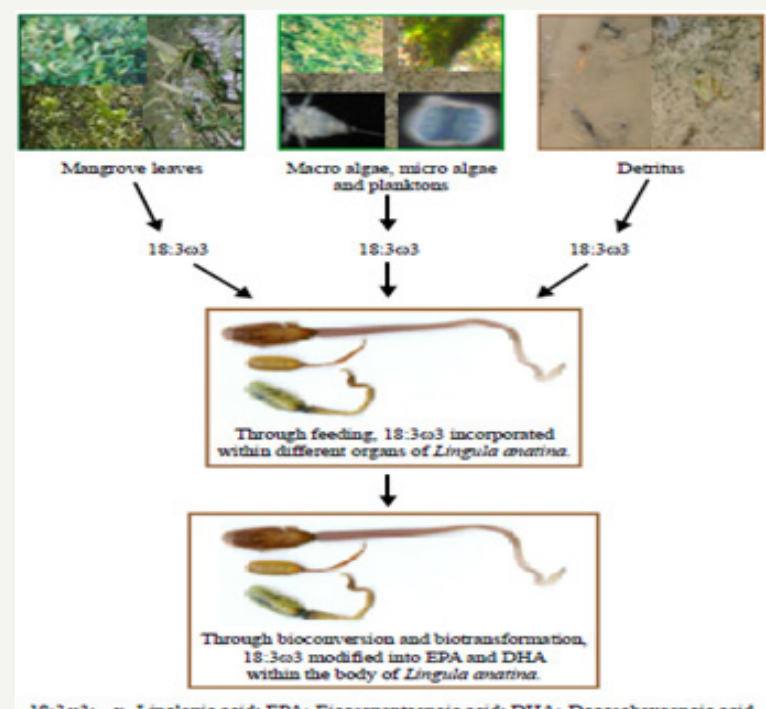

Figure 6: Litter decomposition by Brachiopod or Lingula anatina(a Brachyopod).

\section{Results}

Analysis of lipid contents of food sources of studied benthic animals have revealed that planktons (S1) contained the highest amount $(0.84 \%)$ of total lipids while detritus exhibited the lowest amount $(0.15 \%)$.Out of nine different parts of animal bodies, muscles (S12) of Lingula anatina were found to exihibit highest amount (2.95\%) and pedicle (S 1) showed the presence of lowest $(0.35 \%)$ amount of total lipids (Table 1) (Figure 7). Percentage of Neutral Lipid (NL), Glycolipid (GL), and Phospholipid (PL) as obtained from total Lipid (TL) of body flesh of Uca acuta acuta and muscles of Lingula anatina have been presented in the (Table 2) (Figure 8). Fractional analyses of different collected samples have revealed the presence of highest amount of saturated fatty acids (SAFA) from detritus and lophophore of Lingula anatina as $53.2 \%$ and $53.3 \%$ respectively whereas, mangrove shrub, Acanthus ilicifolius (S 3) and muscles of Cerebratulus bengalensis (S14) displayed lowest amount of SAFA as $30.2 \%$ and $20.1 \%$ respectively (Tables $3 \& 4$ ) (Figures $9 \& 10$ ). Among a total of fourteen different studied samples, highest amount (27.9\%) of monounsaturated fatty acid (MUFA) was recorded from detritus and highest amount (57.54\%) of polyunsaturated fatty acid (PUFA) was estimated from another mangrove shrub, Suaeda maritima (S4) as shown in the (Tables $3 \& 4$ ) respectively. Out of fourteen different SAFA estimated from fourteen different samples, only Arachidic acid (20:0) has been recorded from muscles of Cerebratulus bengalensis. The same animal also showed the presence of considerable amount of Gondoic acid (20:1).

Table 1: Percentage of total lipid (TL, \% w/w) obtained from various body parts of studied animals and their food sources.

\begin{tabular}{|c|c|c|c|}
\hline Samples & Amount Taken (gm) & Total Lipid Obtained (mg) & Percentage of Total Lipid(w/w) \\
\hline Planktons (S 1) & 2.8 & 23.6 & 0.84 \\
\hline \multicolumn{4}{|c|}{ Mangrove Leaves } \\
\hline Avicennia marina (S 2) & 15 & 94.8 & 0.63 \\
\hline Acanthus ilicifolius (S 3) & 15 & 29.2 & 0.19 \\
\hline Suaeda maritima (S 4) & 15 & 38 & 0.25 \\
\hline Detritus (S 5) & 9.63 & 14.2 & 0.15 \\
\hline \multicolumn{4}{|c|}{ Uca acuta acuta } \\
\hline Body flesh (S 6) & 30 & 240.2 & 0.81 \\
\hline Big chela flesh (S 7) & 5 & 33 & 0.66 \\
\hline Gut content (S 8) & 5 & 59.5 & 1.19 \\
\hline Hepatopancreas (S 9) & 11.41 & 161.5 & 1.42 \\
\hline \multicolumn{4}{|c|}{ Lingula anatina } \\
\hline Lophophore (S 10) & 1.08 & 8.5 & 0.79 \\
\hline Pedicle (S 11) & 3.2 & 11.2 & 0.35 \\
\hline Muscle (S 12) & 4.27 & 126.1 & 2.95 \\
\hline Gut content (S 13) & 0.56 & 11.7 & 2.09 \\
\hline \multicolumn{4}{|c|}{ Cerebratulus bengalensis } \\
\hline Muscles (S 14) & 5.23 & 125.54 & 2.39 \\
\hline
\end{tabular}


The $\alpha$ linolenic acid (18:3 $\omega 3$ ) exhibited highest amount (39.6\%) in the mangrove leaves, Avicennia marina, whereas its quantity suddenly decreased in all three animal samples as recorded during present research works (Table $2 \& 3$ ). Out of thirty different fatty acids, thirteen categories have not been detected from mangrove leaves but have been found from animal samples which included $17: 2,20: 3 \omega 3,20: 4 \omega 6,20: 5 \omega 3,21: 5 \omega 3,22: 5 \omega 6,22: 5 \omega 3$ and

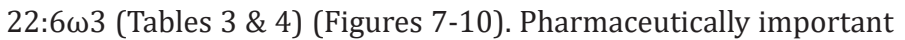
Docosahexaenoic acid (DHA) has not been encountered from Cerebratulus bengalensis. Among all presently studied animals, only Lingula anatina has been found to contain Arachidonic acid and Eicosapentaenoic acid in higher amount (10.4\% and 15.8\%) which have been presented in the Table 4. Fractional components of fatty acids as represented in the Table 3 , showed that food components of Cerebratulus bengalensis. included appreciable amount of $\alpha$ linolenic acid (ALA). Muscles of Cerebratulus bengalensis. have shown to contain 9 different types of MUFAs and 12 different types

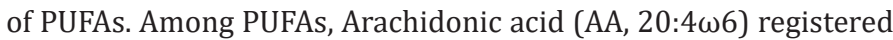
highest amount (5.00\%) followed by Eicosatrienoic acid (ETE,

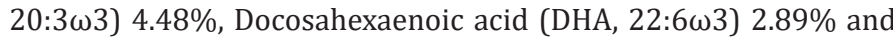
so on. However, mangrove leaves did not reveal the occurrence of AA, ETE (Eicosatrienoic acid) and DHA (Docosahexaenoic acid).

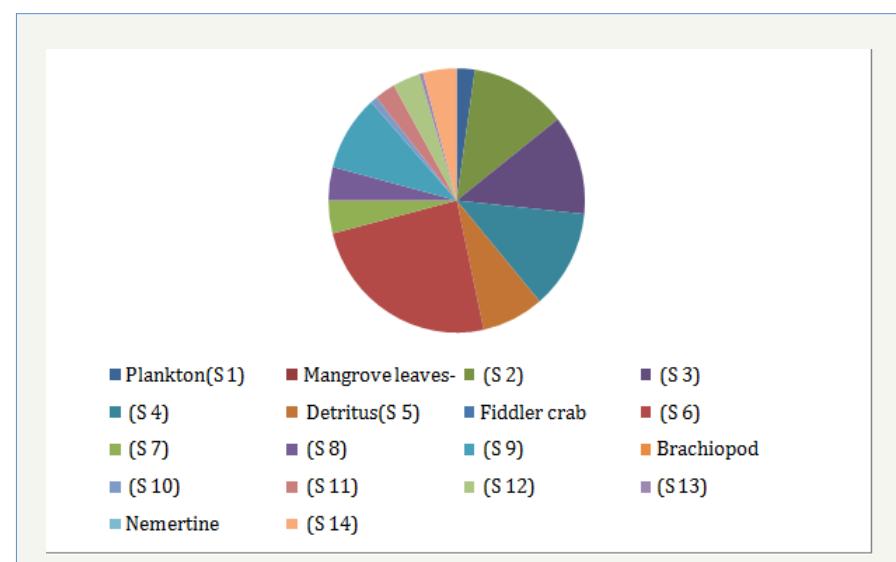

Figure 7: Percentage of total lipid (TL w/w) obtained from various body parts of studied animals and their food sources.
Table 2: Percentage of Neutral Lipid (NL), Glycolipid (GL), and Phospholipid (PL) obtained from total Lipid (TL) of Body flesh of Uca acuta acuta and Muscle of Lingula anatina.

\begin{tabular}{|c|c|c|c|}
\hline \multicolumn{2}{|c|}{ Uca acuta acuta } & \multicolumn{2}{c|}{ Lingula anatina } \\
\hline Neutral lipid (NL, \% w/w) & 38.9 & $\begin{array}{c}\text { Neutral lipid (NL, \% } \\
\text { w/w) }\end{array}$ & 34.55 \\
\hline Glycolipid (GL, \% w/w) & 8.4 & Glycolipid (GL, \% w/w) & 11.41 \\
\hline Phospholipid (PL, \%w/w) & 52.66 & $\begin{array}{c}\text { Phospholipid (PL, \% } \\
\text { w/w) }\end{array}$ & 54.03 \\
\hline
\end{tabular}

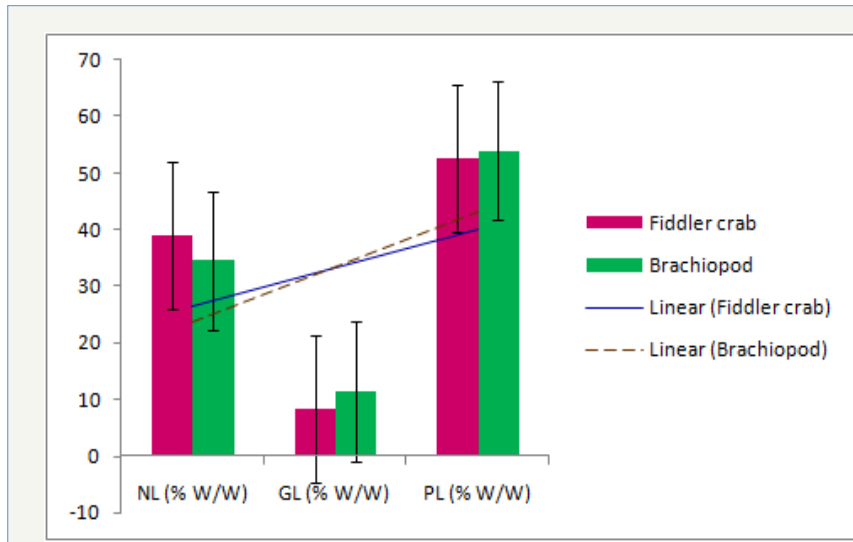

Figure 8: Percentage of Neutral Lipid (NL), Glycolipid (GL), and Phospholipid (PL) obtained from total Lipid (TL) of Body flesh of Uca acuta acuta and Muscle of Lingula anatina.

From the present study, it was also noted that Uca acuta acuta contained seven different types of SAFAs and MUFAs and thirteen different types of PUFAs. Out of thirty various kinds of fatty acids (FA), seven categories of SAFAs, six categories of MUFAs and fourteen categories of PUFAs have been recorded from different studied body parts of Lingula anatina (Table 4) (Figure 8) It was also found that PUFA/ SAFA ratio displayed very lower value. Interestingly, it

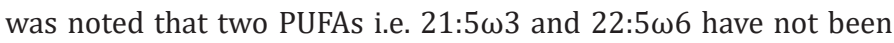
recorded from Cerebratulus bengalensis and Uca acuta acuta. All the qualitative and quantitative information regarding estimated and reported fatty acids which have been considered as biomarkers are being presented in the Tables 3-5 \& Figure 8.

Table 3: Fractional compositions of fatty acids of total lipids in different food samples of studied animals as determined by GLC of methyl esters (\% $\mathrm{w} / \mathrm{w}$ of each component in total fatty acids).

\begin{tabular}{|c|c|c|c|c|c|c|}
\hline \multirow[t]{2}{*}{ Componentsa } & \multirow[t]{2}{*}{ FA Name } & \multirow{2}{*}{$\begin{array}{c}\text { Plankton } \\
\text { S } 1\end{array}$} & \multicolumn{3}{|c|}{ Mangrove leaves } & \multirow{2}{*}{$\begin{array}{c}\text { Detritus } \\
\text { S } 5\end{array}$} \\
\hline & & & S 2 & S 3 & S 4 & \\
\hline $14: 0$ & Myristic & 9.0 & 0.5 & 1.1 & 0.5 & 6.5 \\
\hline $15: 0$ & Pentadecanoic & 1.3 & 1.4 & 1.0 & 1.8 & 2.4 \\
\hline $16: 0$ & Palmitic & 20.4 & 35.2 & 22.1 & 29.7 & 38.2 \\
\hline $17: 0$ & Margaric & 1.1 & 0.9 & 0.8 & 0.4 & 0.6 \\
\hline 18:0 & Stearic & 9.5 & 3.5 & 4.9 & 5.1 & 4.4 \\
\hline $20: 0$ & Arachidic acid & & & & & \\
\hline $22: 0$ & Behenic & 0.3 & 0.1 & 0.1 & & 0.4 \\
\hline $24: 0$ & Lignoceric & 1.3 & & 0.2 & 0.2 & 0.7 \\
\hline Total SAFA & & 42.90 & 41.60 & 30.2 & 37.7 & 53.2 \\
\hline $14: 1$ & etradedecenoic & 0.3 & & & & 2.7 \\
\hline
\end{tabular}




\begin{tabular}{|c|c|c|c|c|c|c|}
\hline $15: 1$ & Pentadecenoic & 0.1 & & 0.3 & 0.5 & 0.6 \\
\hline $16: 1$ & Palmitoleic & 10.8 & 1.5 & 1.8 & 1.3 & 11 \\
\hline $17: 1$ & Heptadecenoic & 1.7 & 0.4 & 0.3 & & 0.3 \\
\hline $18: 1 \omega 9$ & Oleic & 5.3 & 14.4 & 13.1 & 2.3 & 13.2 \\
\hline $20: 1$ & Gondoic acid & & & & & \\
\hline $22: 1$ & Erucic acid & 0.2 & & & & 0.1 \\
\hline $24: 1$ & Tetracosanoic & 0.2 & & & & \\
\hline Total MUFA & & $18.6 \mathrm{z}$ & 16.3 & 15.5 & 4.1 & 27.9 \\
\hline $16: 2$ & Hexadecadienoic & 0.2 & & 0.4 & & 1.1 \\
\hline $17: 2$ & Heptadecadienoic & 2.2 & & & & \\
\hline $18: 2 \omega 6$ & Linoleic & 1.9 & 10.3 & 21.9 & 17.3 & 9 \\
\hline $18: 3 \omega 6$ & $\gamma$ linolenic & 0.3 & 1.1 & 0.1 & 0.2 & 1.5 \\
\hline $18: 3 \omega 3$ & $\alpha$ linolenic & 3.1 & 30.1 & 31 & 39.6 & 2.7 \\
\hline $20: 3 \omega 3$ & Eicosatrienoic & 0.1 & & & & 0.3 \\
\hline $20: 4 \omega 6$ & Arachidonic & 2.6 & & & & 0.2 \\
\hline $20: 4 \omega 3$ & Eicosatetraenoic & 1.9 & 0.1 & 0.3 & 0.4 & 1.3 \\
\hline $22: 4 \omega 6$ & Adrenic & 0.6 & 0.04 & 0.1 & 0.04 & \\
\hline $20: 5 \omega 3$ & Eicosapentaenoic & 12.5 & & & & 1.2 \\
\hline $21: 5 \omega 3$ & Heneicosapentaenoic & 0.1 & & & & \\
\hline $22: 5 \omega 6$ & Osbond, $\omega 6 \mathrm{DPA}$ & 0.2 & & & & 0.04 \\
\hline $22: 5 \omega 3$ & Clupanodonic, DPA & 1 & & & & 0.02 \\
\hline $22: 6 \omega 3$ & Docosahexaenoic & 11.1 & & & & 0.2 \\
\hline Total PUFA & & 37.8 & 41.64 & 53.8 & 57.54 & 17.56 \\
\hline Total $-\omega 3$ & & 29.8 & 30.2 & 31.3 & 40 & 5.72 \\
\hline Total $-\omega 6$ & & 5.6 & 11.44 & 22.1 & 17.54 & 10.74 \\
\hline PUFA/SAFA & & 0.89 & 1 & 1.78 & 1.52 & 0.33 \\
\hline
\end{tabular}

Table 4: Fractional compositions of fatty acids of total lipids in different body parts of studied animals as determined by GLC of methyl esters (\% $\mathrm{w} / \mathrm{w}$ of each component in total fatty acids).

\begin{tabular}{|c|c|c|c|c|c|c|c|c|c|}
\hline Components $^{\mathbf{a}}$ & Uca acuta acuta & & & & Lingula anatina & & & & Cerebratulus bengalensis \\
\hline & S 6 & S 7 & S8 & S9 & S 10 & S 11 & S 12 & S 13 & S 14 \\
\hline $14: 0$ & 2.2 & 4.3 & 4 & 6.9 & 1.4 & 0.9 & 4.5 & 3.1 & 1 \\
\hline $15: 0$ & 2.3 & 4.5 & 1.8 & 0.4 & 0.9 & 1.2 & 1.3 & 1.3 & 1.26 \\
\hline $16: 0$ & 21.6 & 18.7 & 25.5 & 13.6 & 23 & 23.4 & 14.7 & 23.2 & 7.96 \\
\hline $17: 0$ & 2.5 & 1.3 & 2.6 & 3 & 3.3 & 2.9 & 1.8 & 1.9 & 1.71 \\
\hline $18: 0$ & 9.4 & 12.4 & 10.2 & 10.7 & 21.3 & 19.8 & 11.7 & 10.1 & 5.32 \\
\hline $20: 0$ & & & & & & & & & 2.01 \\
\hline $22: 0$ & 0.4 & 0.1 & 0.6 & 0.3 & 0.7 & 0.8 & 0.5 & 1 & 0.62 \\
\hline $24: 0$ & 0.7 & 0.5 & 0.3 & 1 & 2.7 & 2.8 & 1.2 & 0.6 & 0.13 \\
\hline Total SAFA & 36.9 & 41.8 & 45 & 35.9 & 53.3 & 51.8 & 35.7 & 41.2 & 20.01 \\
\hline $14: 1$ & & & & 0.1 & & & & & 0.86 \\
\hline $15: 1$ & 0.7 & & 0.3 & 0.3 & & 1.0 & & & 0.20 \\
\hline $16: 1$ & 9.9 & 8 & 17.4 & 10.3 & 4.5 & 1.5 & 8.3 & 8.7 & 1.66 \\
\hline $17: 1$ & 0.6 & 2.6 & 1.1 & 3.9 & 0.7 & 5.2 & 1.3 & 1.3 & 0.8 \\
\hline $18: 1 \omega 9$ & 6.3 & 7.2 & 7.3 & 9.6 & 4.2 & 3.4 & 8.5 & 7 & 3.02 \\
\hline $20: 1$ & & & & & & & & & 0.29 \\
\hline $22: 01$ & 0.1 & 1.0 & 0.2 & 0.3 & 0.5 & 0.7 & 1.1 & 0.2 & 0.57 \\
\hline $24: 1$ & 0.4 & 1.0 & 0.6 & 0.7 & 0.6 & 0.9 & 0.4 & & 0.66 \\
\hline Total MUFA & 18 & 19.8 & 26.9 & 25.2 & 10.5 & 12.7 & 19.6 & 34.4 & \\
\hline
\end{tabular}




\begin{tabular}{|c|c|c|c|c|c|c|c|c|c|}
\hline $16: 02$ & 0.2 & & 2.0 & 2.5 & 0.1 & 0.6 & 0.1 & 0.2 & \\
\hline $17: 02$ & & & & & 2.3 & 0.5 & 0.1 & 0.1 & \\
\hline $18: 2 \omega 6$ & 2.9 & 4.7 & 3.9 & 4.4 & 1.2 & 1.2 & 1.8 & 1.9 & 1.84 \\
\hline $18: 3 \omega 6$ & 0.5 & 0.4 & 0.5 & 1.2 & 0.1 & & & 0.2 & 0.46 \\
\hline $18: 3 \omega 3$ & 0.3 & 0.3 & 0.4 & 1.0 & 1.0 & 0.7 & 3.5 & 2.5 & 1.36 \\
\hline $20: 3 \omega 3$ & 0.2 & 1.5 & 0.3 & 0.1 & 0.1 & 0.5 & 0.1 & 0.1 & 4.48 \\
\hline $20: 4 \omega 6$ & 0.1 & & 0.1 & 0.7 & 10.4 & 9.6 & 7.6 & 5.3 & 5 \\
\hline $20: 4 \omega 3$ & 6.2 & 8.4 & 7.6 & 9.8 & 2.4 & 2.3 & 2 & 2.1 & \\
\hline $22: 4 \omega 6$ & 0.1 & 0.1 & 0.1 & 0.2 & 0.5 & & 0.8 & 0.8 & \\
\hline $20: 5 \omega 3$ & 2.3 & 14.3 & 10.3 & 13.3 & 10.1 & 12.7 & 14.4 & 15.8 & \\
\hline $21: 5 \omega 3$ & 0.1 & & & 0.2 & 0.2 & & 0.04 & & \\
\hline $22: 5 \omega 6$ & & & & 0.007 & 0.7 & 0.9 & 0.6 & 2.1 & \\
\hline $22: 5 \omega 3$ & 0.1 & 0.2 & 0.1 & 0.2 & 1.3 & 1.6 & 2.4 & 1.6 & \\
\hline $22: 6 \omega 3$ & 9.3 & 7 & 2.5 & 4.8 & 5.2 & 4.5 & 10.3 & 7.9 & 2.89 \\
\hline Total PUFA & 22.3 & 36.9 & 27.8 & 38.40 & 35.6 & 35.1 & 43.74 & 40.60 & 16.03 \\
\hline Total $-\omega 3$ & 18.5 & 31.7 & 21.2 & 29.4 & 20.3 & 22.3 & 32.74 & 30 & 8.73 \\
\hline Total $-\omega 6$ & 3.6 & 5.2 & 4.6 & 6.5 & 12.9 & 11.7 & 10.8 & 10.3 & 7.3 \\
\hline PUFA/SAFA & 0.60 & 0.88 & 0.60 & 1.06 & 0.66 & 0.67 & 1.22 & 0.98 & 0.80 \\
\hline
\end{tabular}

Table 5: Fatty Acid Designations, Names And Some Recent Uses As Biomarkers As Reported By Samanta et al. [19,21].

\begin{tabular}{|c|c|c|}
\hline Components $^{\mathrm{a}}$ & Fatty Acid Name & Biomarker for \\
\hline $14: 0$ & Myristic & Protobacteria, Diatoms, Prymnesiophytes \\
\hline 15:0 & Pentadecanoic & Phytoplancton \\
\hline $16: 0$ & Palmitic & Mangrove leaves \\
\hline $17: 0$ & Margaric & Bacteria \\
\hline $18: 0$ & Stearic & Mangrove leaves \\
\hline $22: 0$ & Behenic & Terrestyrial Plants \\
\hline $24: 0$ & Lignoceric & Mangrove and Terrestrial Plants \\
\hline $14: 1$ & Tetradedecenoic & Proteobacteria \\
\hline $15: 1$ & Pentadecenoic & Bacteria. \\
\hline $16: 1$ & Palmitoleic & Planktons, Mangroves \\
\hline $17: 1$ & Heptadecenoic & Bacteria \\
\hline $18: 1 \omega 9$ & Oleic & Crustacea, Deep Sea fish, Macroalgae, Mangrove, Carnivory \\
\hline $24: 1$ & Tetracosanoic & Zooplzncton \\
\hline $16: 2$ & Hexadecadienoic & Planktons, Mangrove leaves \\
\hline 17:02 & Heptadecadienoic & Planktons \\
\hline $18: 2 \omega 6$ & Linoleic & Mangrove, Sea grass, Macroalgae, Vascular plants, \\
\hline $18: 3 \omega 6$ & $\gamma$ linolenic & Macro algae \\
\hline $18: 3 \omega 3$ & $\alpha$ linolenic & Mangrove, Sea grass, Vascular plant \\
\hline $20: 3 \omega 3$ & Eicosatrienoic & Not reported from plant materials \\
\hline $20: 4 \omega 6$ & Arachidonic & Protozoa, Micro eukaryotes, Red algae, Kelp \\
\hline $20: 4 \omega 3$ & Eicosatetraenoic & Fungi, Protozoa, Algae \\
\hline $22: 4 \omega 6$ & Adrenic & Phytoplanktons (Euglenophyceae) \\
\hline $20: 5 \omega 3$ & Eicosapentaenoic & Diatom, Brown and Red Macro algae \\
\hline $21: 5 \omega 3$ & Heneicosapentaenoic & Planktons \\
\hline $22: 5 \omega 6$ & Osbond, $\omega 6 \mathrm{DPA}$ & Phytoplanktons(Ocromonadeles, Cryptophyceae) \\
\hline $22: 5 \omega 3$ & Clupanodonic, DPA & Diatoms \\
\hline $22: 6 \omega 3$ & Docosahexaenoic & Zooplankton \\
\hline
\end{tabular}




\section{Discussion}

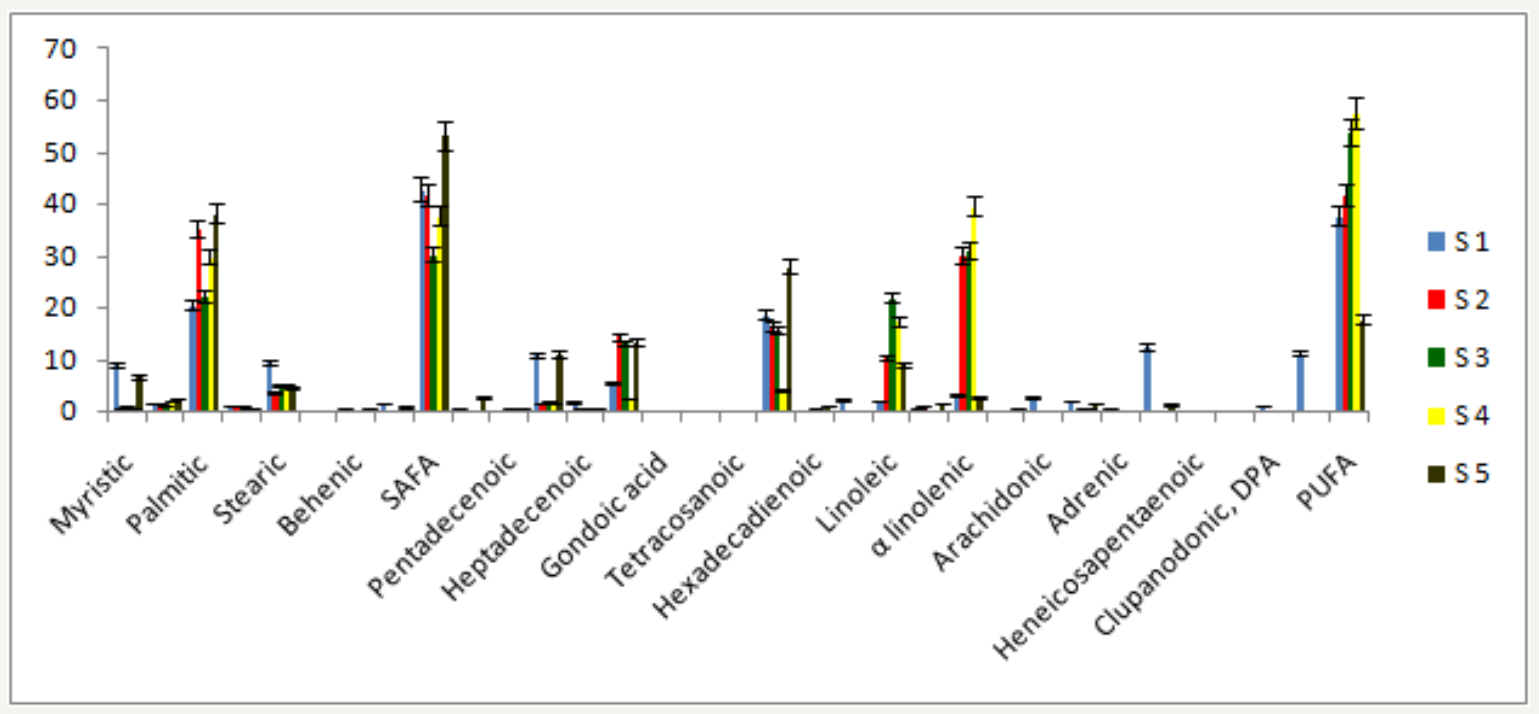

Figure 9: Fatty acid compositions of various food sources of studied animals (\% w/w of each component).

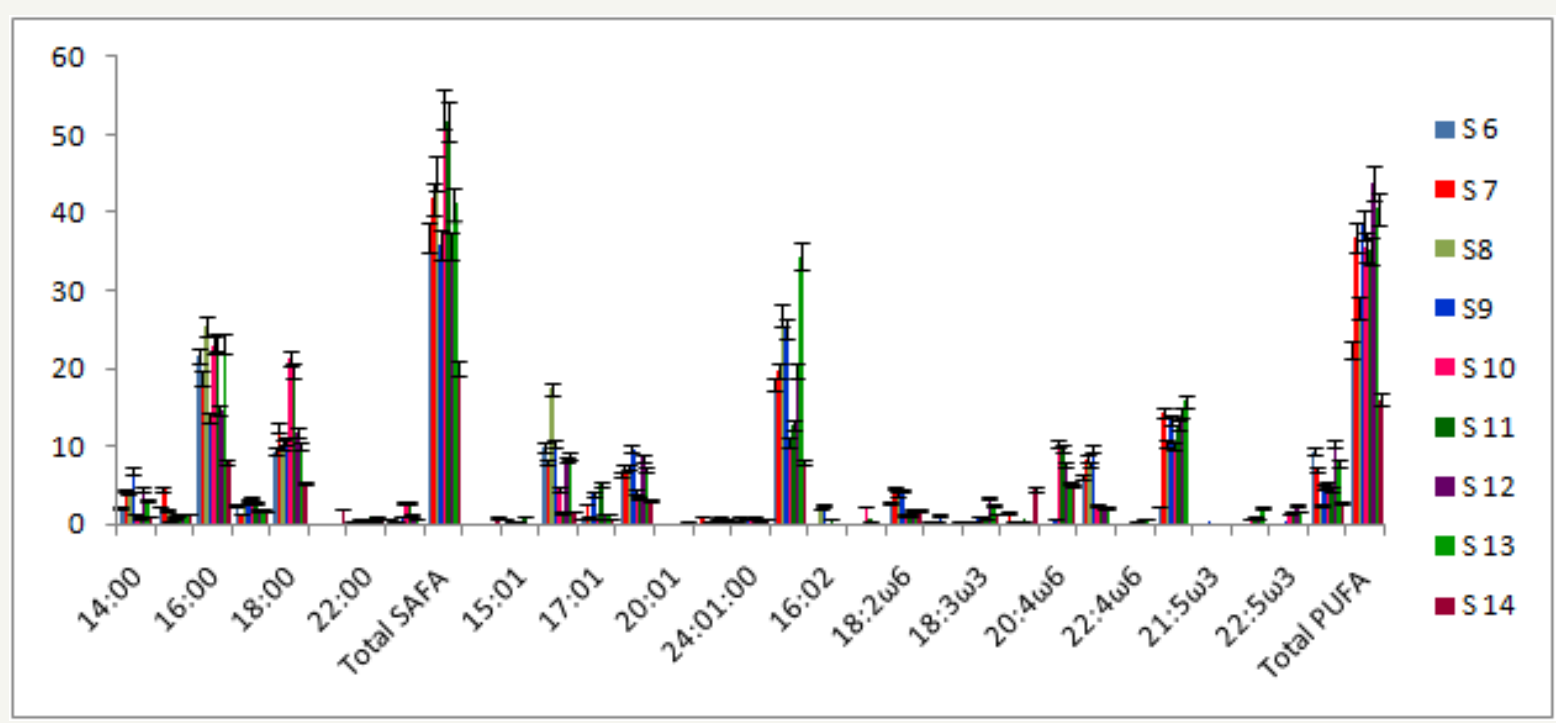

Figure 10: Fatty acid compositions of different body parts of studied animals ( $\% \mathrm{w} / \mathrm{w}$ of each component).

Ecosystem management is based on understanding of how natural systems work and how human activities may influence these systems. Biodiversity has a fundamental role in providing the basis for all ecosystem goods and services [4]. It should also be emphasized that the coastal ecosystems as evaluated in this paper are strongly linked through bio-geo-physical interactions, suggesting that they cannot easily be treated as separate unit from a management perspective and exhibit connectedness via nutrient fluxes, floral and faunal successions, migrations, etc. The use of one function in any system may influence the availability of other functions, the efficiency of nutrient cycling, energy transfer, and sediment formation influences the biological productivity of a coastal ecosystem [4]. The present investigation has highlighted the mode of occurrence of different classes of fatty acids in body muscles of three mangrove- estuarine benthic macrofauna namely Lingula anatina, Cerebatulus bengalensis \& Uca acuta acuta inhabiting in an ecotone, at the confluence of an estuary (Subarnarekha) with Bay of Bengal (longitude $87^{\circ} 5^{\prime} \mathrm{E}$ to $88^{\circ} 5^{\prime} \mathrm{E}$ and latitude $20^{\circ} 30^{\prime} \mathrm{N}$ to $22^{\circ} 2^{\prime} \mathrm{N}$ ) in the North-East coast of India. Estimation of such biochemical entities has also been made from the habitat of the studied species, especially its food sources (mangrove leaves, planktons and detritus). The variabilities in the amount of different fatty acid components in different body parts of three different studied species and their food sources have prompted to arrive at a conclusion on the mode of biotransformation and bioconversion of these bioactive substances.

Fatty acids have been used as qualitative markers to trace or confirm predator prey relationships in the marine environment for 
more than thirty years [33]. More recently, they have also been used to identify key processes impacting the dynamics of some of the world's major ecosystems. The fatty acid trophic marker concept is based on the observation that marine primary producers lay down certain fatty acid patterns that may be transferred conservatively and hence can be recognized in primary consumers [34]. In a marine ecosystem, generally qualitative similarities are observed in the fatty acid composition of the organisms which occupy different trophic levels. The first link of the food chain i.e. phytoplankton are able to synthesize all the fatty acids de novo and composition of fatty acids changed significantly in the decomposing leaves of mangroves $[4,35,36]$. High concentration of $\omega-3$ fatty acids which are generally considered as to be fatty acids of marine life, were found to have been mainly contributed by some phytoplanktonic species (diatoms, dinoflagellates, etc.) to the marine ecosystem [35]. Examination on various parts of Lingula anatina, an intertidal detritivorous macrobenthic animal of the studied areas revealed the presence of appreciably high amount of 20:5 03 fatty acids associated with other PUFA of the $-\omega 3$ series associated with other polyunsaturated fatty acids of the $-\omega 3$ series (Table 4) (Figure 8). It is thus envisaged that intake of higher amount of the precursor

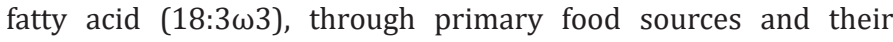
subsequent chain elongations and desaturation processess de novo would lead to the formation of 3- $\omega$ unsaturated fatty acids in higher levels. Intake of these diets enriched with 3- $\omega$ acids may explain the mode of accumulation of these polyunsaturated fatty acids in considerable levels in the different parts of this benthos.

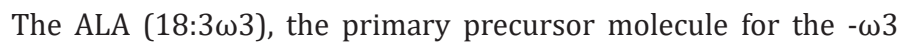
family of fatty acids [37] in animal tissues must come from diet. The principal pathways to the formation of EPA (20:5 $\omega 3)$ and DHA $(22: 6 \omega 3)$ require a sequence of chain elongation and desaturation steps ( $\Delta 5$ and $\Delta 6$ desaturases) with acyl-coenzyme-A esters as substrates [30,31]. The bioconversion of ALA in the present studied faunal component is supposed to occur after being initiated and subsequently derived

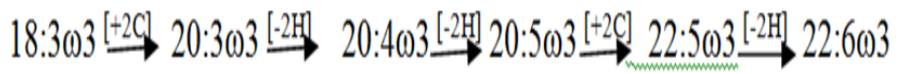

from linolenate $(18: 3 \omega 3)$ which is obtained by the animal from their primary food sources. This finding has been corroborated by the earlier observations of San Giovanni \& Chew [37], Kapoor \& Patil [38].

It is interesting to note the pathways of conversion of different biochemical constituents through the ecosystem functioning in mangrove-estuarine system. Lipids being an important biochemical component in the living organisms play vital physiological functioning [28] and also contribute profusely in the flow of organic materials through food chains and food webs operating in the ecosystem. Studies have been conducted in the coastal Midnapore (East) district to understand the mode of bioconversion and biotransformation of lipids in the following pathway: Mangroves $\rightarrow$ Soil $\rightarrow$ Water $\rightarrow$ Macrodecomposers $\rightarrow$ Microdecomposers $\rightarrow$ Detritus $\rightarrow$ Detritivores (Benthos) $\rightarrow$ Detritus etc. These studies on three different macro benthos (fiddler crab, brachiopod and nemertine) have revealed mode of occurrence and characteristics of different fractional components of fatty acids in different parts of studied fauna and the mode of bioconversion of such biochemical entities. The ultimate outcome was the enrichment of the system with lot of decomposition products through such biogeochemical processes leading to the enrichment of nutrients so that all the biodiversity components get the benefit through trophic relationships [18]. Presence of moderate to high levels of EPA and DHA, within different body parts of studied species, derived through bioconversion of ALA from food sources indicated that they have been the good sources of EPA and DHA which are being considered as the precursors of several metabolites that are potent lipid mediators. Many investigators recognize them as to be the beneficial components for human being as in the prevention or treatment of several diseases [19,39]. Recent investigation has revealed that muscles of the studied animal, L. anatina stored major amount of all fatty acids.

EPA and DHA recorded from plankton samples indicated that $L$. anatina obtains these fatty acids from the planktons as food source. Major mangrove plant leaves of the studied area have been found to possess moderate to high amount of $\alpha$-linolenic acid (18:3 $\omega 3$ ) which is the precursor of long chain PUFAs viz. EPA (20:5 13$)$ and

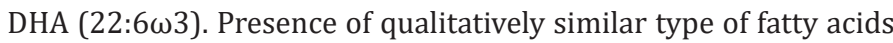
in L. anatina, inhabiting in three contrasting study sites of the Subarnarekha mangrove estuarine complex has enabled to arrive at a conclusion that the occurrence of different morphotypic forms of L. anatina as observed during present study belong to same genus and species [21]. Presence of high levels of carnivorous markers of the studied species i.e. oleic acid (18:1 $\omega 9$, derived from animal sources because of the consumption of zooplankton, animal detritus etc., occurred in the intertidal belts) in different body parts of $L$. anatina have indicated that all those fauna are the co-inhabitants

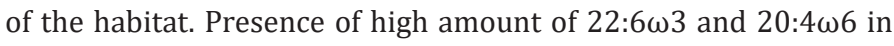
different body parts of L. anatina has established the facts that diatoms, dianoflagellates and macroalgae tended to constitute the basal portion of food pyramid of this complex estuarine ecosystem [20]. Fatty acids are useful tool to study trophic ecology and determine food web connections, contrary to more traditional gut content analysis which provide information on dietary intake and food constituents leading to the sequestration of lipid reserves over a longer period of time [40]. The gut content analysis revealed that food contents of L. anatina have been found to include fragmented mangrove leaves, detritus and planktonic components which is in tune with the earlier findings conducted by [41]. The presence of EPA and DHA within different body parts of L. anatina has strengthened the fact that these pharmaceutically important fatty acids are thought to have been derived from ALA, present in dietary food sources of $L$. anatina through biotransformation processes within the body of this rare benthic brachiopodan faunal component. It was recorded that phospholipids obtained from muscles of L. anatina were the major classes of lipids which form structural and functional components of cell membranes.

Presence of moderate to high levels of EPA and DHA, within different body parts of studied species, derived through bioconversion of ALA from food sources indicated that they have 
been the good sources of EPA and DHA which are being considered as the precursors of several metabolites that are potent lipid mediators. Many investigators recognize them as to be the beneficial components for human being as in the prevention or treatment of several diseases $[19,39]$. Recent investigation has also revealed that muscles of the studied animal, L. anatina stored major amount of all fatty acids. The Uca species of the present study grazes on the leaf detritus $[17,10]$ and thus consumes considerable amount of

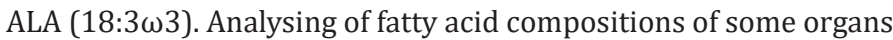
viz. body flesh, big chela flesh, hepatopancreas and gut content of an abundant fiddler crab species, Uca acuta acuta, feeding mostly on the detritus, have revealed the occurrence of different fractional fatty acid components, as shown in the Table 4 which are mostly derived from the decomposition product of mangrove leaves $[25,26]$. The most common constituent of the soluble lipids of the plant cuticle are wax esters, defined as fatty acid esters of fatty alcohols [42]. Generally the unsaturated fatty acids of plant leaf surface waxes of mangrove plant leaves composed of mono-, di- and trienoic moieties containing 18-carbon chains [43]. This observation has also been confirmed in the present study. Besides, special mention can be made on $\alpha$-linolenic acid (ALA, 18:3 $\omega 3$ ) which is the precursor of the long chain polyunsaturated fatty acids (PUFA's) of $-\omega 3$ series, viz., Eicosapentaenoic acid (EPA, 20:5 $\omega 3$ ) and Docosahexaenoic acid (DHA, 22:6w3. The Uca species of the present study grazes on the leaf detritus [44] and thus consumes

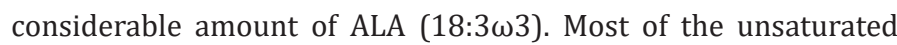
fatty acids have been utilized by various organisms including $U c a$, whereas a part of those washed out by the tidal water [44]. Different organs of Uca acuta acuta showed the presence of $\alpha$-linolenic acid $(18: 3 \omega 3)$ in considerable amount (about $30-40 \%)$ which constitute the leaf lipids of major plants of this area. Alfa linolenic acid (ALA, $18: 3 \omega 3$ ) is the primary precursor molecule for the $-\omega 3$ family of fatty acids in animal tissues, must come from the diet i.e., from the plant leaves. On the other hand, the detritus contained only $2.7 \%$ of ALA. This signifies that the leaf litters formed out of breakdown of mangrove leaves and after being exposed to tidal waters, and microbial activities undergo decomposition processes and detritus is formed [11].

Since only a small portion (5\%) of the leaf material was found to have been removed by grazing insects before leaf abscission, most of the material become widely dispersed by seasonal currents. A key group of small animals, comprising only a few species but very large number of individuals, (in the present study Uca acuta acuta being one) ingest large quantities of the vascular plant detritus, and thus participates in the food chain. It is clear that the Uca acuta acuta species consumes considerable amounts of ALA (18:3 $\omega 3$ ), by grazing on the detritus. Only fragmentary studies have [45] so far been made on the transmission of plant biochemicals to detritivore animals and their bio-converion there upon of the studies so far done, in the Sunderbans mangrove forest, mention can be made of the fatty acids and sterols of mangrove leaves [43], triterpenoids and sterols of mangrove plant leaves [29] and fatty acids of the detritivores, Boleophthalmus boddarti [46] and biotransformation of oleanolic acid to oleanonic acid of mangrove leaves [43]. Based on the investigation on the role of a dominant fiddler crab species, Uca acuta acuta on the biotransformation of plant biochemicals especially of lipid and fatty acid components from plants to detritus and there from to benthic fauna such as fiddler crab, of Midnapore (East) coastal tract, West Bengal, India the following inferences can be drawn:

A. The mangrove plant leaves of the study area contains high levels of $\alpha$-linolenic acid (18:3 $\omega 3)$, which is a precursor of long

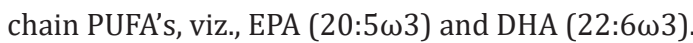

B. Uca acuta acuta is an important bio-energetically significant benthic animal on the leaf detritus, and thus consumes considerable amount of $\alpha$-linolenic acid (ALA, 18:3 $\omega 3$ ).

C. The ALA thus consumed by this abundant grazing animal in the estuarine mud flat in this area, are converted in vivo to long chain polyunsaturated fatty acids of $-\omega 3$ series, viz., EPA and DHA.

D. Considerably high levels of EPA and DHA have been found in the various samples of Uca acuta acuta, particularly in the body flesh of the animal.

E. Through this study, it has been established that, Uca acuta acuta are capable of biosynthesizing long chain PUFA's efficiently [25-26].

Examination on muscles of Cerebratulus bengalensis, an intertidal detritivorous macrobenthic nemertine of the studied areas revealed the presence of appreciably high amount of 20:5 $\omega 3$ fatty acids associated with other polyunsaturated fatty acids of the $-\omega 3$ series. It is thus envisaged that intake of higher amount of the precursor acid (18:3 $\omega 3)$, through primary food sources and their subsequent chain elongations and desaturation processes de novo would lead to the formation of $-\omega 3$ unsaturated fatty acids in higher levels. Intake of these diets enriched with $-\omega 3$ acids may explain the mode of accumulation of these PUFAs in variable amounts in the body parts (muscles) of studied macrobenthic estuarine fauna. Low values of the PUFA/SAFA ratio as determined in the present research investigation are because of the presence of higher levels of Palmitic acid (16:0), suggesting a contribution of vegetal detritus in the diet of Cerebratulus bengalensis. PUFAs

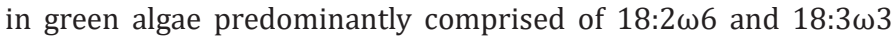
and these fatty acid compositions are similar to those of terrestrial (Vascular) plants since they have common ancestors. In the present

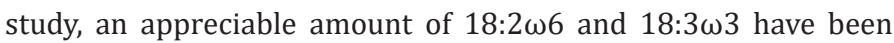
estimated indicating that the species under study used to consume considerable amount of green algae (phytoplankton) occurring over the surface of the soil and also from the supply of neighboring mangrove vegetations. Terrestrial organic matters can also be associated with bacteria or fungi and constitutes an attractive and energetically utilizable food sources for invertebrates [47]. In the present study, the odd branched fatty acids have been recorded as an indicator of bacterial derivative which highlights a source of food supply for Cerebratulus bengalensis from decaying organic

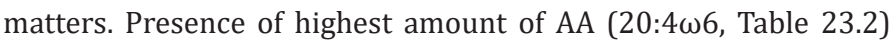
in the muscles of studied species further indicated that detritus 
serves as one part of food of Cerebratulus bengalensis. Presence of moderate to high levels of EPA and DHA, within muscles of studied species, derived through bioconversion of ALA from food sources indicated that they have been the good sources of EPA and DHA which are being considered as the precursors of several metabolites that are potent lipid mediators. Many investigators recognize them as to be the beneficial components for human being as in the prevention or treatment of several diseases [39]. Lipid has been recognized as essential component in animal nutrition as well as aquaculture feed. Therefore, deposition of lipid (Fatty acid) which was found as a major constituent in methanolic extract of Cerebratulus bengalensis. might be obtained from their food. These compounds help defend Cerebratulus bengalensis. against predators. The invented chemical defenses are thought to provide ecological advantages and may function as a driving force in the evolution of this group [48]. The present research investigation has revealed that muscles of the studied animal stored major amount of all fatty acids and presence of EPA and DHA in plankton samples indicated that Cerebratulus bengalensis obtains these fatty acids from the planktons as food source. Major mangrove plant leaves of the studied area have been found to possess moderate to high amount of $\alpha$-linolenic acid (18:3 $\omega 3)$ which is the precursor of long

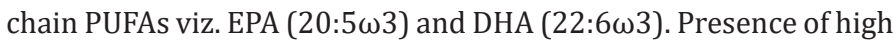
levels of carnivorous markers of the studied species i.e. Oleic acid (18:1 $\omega 9$, derived from animal sources because of the consumption of zooplankton, animal detritus etc., occurred in the intertidal belts) in muscles of Cerebratulus have indicated that they are the inhabitants of the studied ecotone. Presence of high amount of

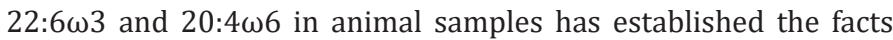
that diatoms, dianoflagellates and macroalgae constitute the basal portion of food pyramid of this complex estuarine ecosystem [24].

The Eicosatrienoic acid has been reported to induce spawning in the male lugworm, Arenicola marina [49]. The highest amount ETE among all detected fatty acids during present investigation indicated the fact that this particular FA is thought to play important role in their reproductive strategy during breeding period. The ability of PUFAs, particularly GLA ( $\gamma$-linolenic acid), recorded during present FA analysis has tended to enhance free radical generation and lipid peroxidation process specifically in tumor cells which is supposed to be because of their tumoricidal actions [50]. An investigation on the mode of occurrence of different classes of fatty acids in body muscles of a mangrove- estuarine benthic macrofauna, Cerebratulus bengalensis. has shown the variabilities in the amount of different fatty acid components in the muscles of studied species and its food sources (Table 4) (Figure 8) which have prompted to arrive at a conclusion on the mode of biotransformations and bioconversions of these bioactive substances. Presence of high levels of carnivorous markers of the studied specieses i.e. oleic acid (18:1 $\omega 9$, derived from animal sources because of the consumption of zooplankton, animal detritus etc, occurred in the intertidal belts) in muscles of Cerebratulus bengalensis, Lingula anatina and Uca acuta acuta have indicated that they are the inhabitants

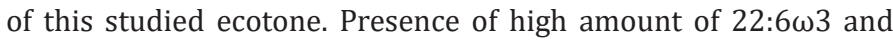

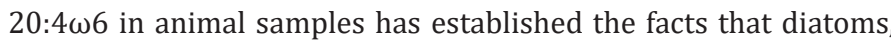

dianoflagellates and macroalgae constitute the basal portion of food pyramid of this complex estuarine ecosystem. Icosanoic acid (20:0) detected at low levels only in Cerebratulus bengalensis. leads to an inference that this is supposed to have been derived from other sources like microorganisms than presently observed food sources. Saturated fatty acids from 20:0 to 26:0 in amide linkage to long-chain bases are normal and important constituents of animal sphingolipids. While very-long-chain saturated fatty acids (22:0 to 32:0) are not usually considered to be common constituents of lipids, they do occur in many plant waxes, which by some estimates are the most abundant lipids in living tissues on earth, and they are also found in some animal waxes such as Cerebratulus bengalensis [51]. The study of lipid flow among trophic levels is important for models of both population dynamics and of bioaccumulation of hydrophobic chemicals [52-55]. Fatty acids are important not only for their impact on animal growth but also on many other facets of functions like reproduction, immunity, ionic balance regulation and even buoyancy regulation and buoyancy control.

\section{Acknowledgement}

The authors are thankful to the authority of Vidyasagar University, Midnapore-721212, W.B., India for providing library and laboratory facilities ; Dr. Chiranjib Pradhan, Scientist, National Institute of Nutrition, Hyderabad, India and Dr. Amitava Ghosh, exScientist ,Bose Institute , Kolkata, West Bengal, India, for analysis of Lipid materials. The continuous inspiration and suggestions given by Professor Amalesh Choudhury, Retired Professor, Department of Marine Science, Calcutta University, West Bengal, India is also thankfully acknowledged.

\section{References}

1. Costanza R, d'Arge R, deGroot R, Farber S, Grasso M, et al. (1997) The value of the world's ecosystem services and natural capital. Nature 387: 253-260.

2. Chapin FS, Zavaleta ES, Eviners VT, Naylor RL, Vitousek PM, et al. (2000) Consequences of changing biodiversity. Nature 405: 234-242.

3. Schlesinger WH (1997) Biogeochemistry: An Analysis of Global Change. In: Schlesinger WH (Ed.), An Analysis of Global Change. ( $2^{\text {nd }}$ edn), CA: Academic, USA, pp. 1-445.

4. Chakraborty SK (2017) Ecological services of intertidal benthic fauna and the sustenance of coastal wetlands along the Midnapore(East) coast, West Bengal, India. In: Finkl CW, Makowski C (Eds.), Coastal Wetlands: Alteration and Remediation, Volume 2, Springer International Publishing, Germany, pp. 777- 866.

5. Polis GA, Anderson WB, Holt RD (1997) Toward an integration of landscape and food web ecology: the dynamics of spatially sub- sidized food webs. Annual Review Ecology Systematics 28: 289-316.

6. Carpenter SR, Kitchell JF, Hodgson JR (1985) Cascading trophic interactions and lake productivity: Fish predation and herbivory can regulate Lake ecosystem. BioScience 35(10): 634-639.

7. Kitchell JF, O'Neill RV, Webb D, Gallepp GW, Bartell SM, et al. (1979) Consumer regulation of nutrient cycling. BioScience 29(1): 28-34.

8. Smith VH (1998) Cultural eutrophication of inland, estuarine, and coastal waters. Successes, Limitations and Frontiers in Ecosystem Science pp. 7-49.

9. Sirotnak JM, Huntly NJ (2000) Direct and indirect effects of herbivores on nitrogen dynamics: voles in riparian areas. Ecology 81(1): 78-87. 
10. Heald EJ (1969) The production of organic detritus in a South Florida Estuary, Dissertations from Pro Quest 1-110.

11. Odum WE, Heald FJ (1975) The detritus based food web of an estuarine mangrove community. In: Cronin LE (Ed.), The detritus based food web of an estuarine mangrove community. Estuarine Research, Volume 1, Academic Press, New York, USA, pp. 265-286.

12. Chakraborty SK (1995) Aquaculture potential of mangrove ecosystem of Sundarbans, India. Proceedings of Seminar on Fisheries-a multimillion dollar industry. AFI, pp.72-83.

13. Chakraborty SK, Giri S, Chakravarty G, Bhattacharya N (2009) Impact of eco-restoration on the biodiversity of Sundarbans mangrove ecosystem, India. Water, Air, Soil Pollution: Focus 9(3-4): 303-320.

14. Chakraborty SK (2011) Mangrove ecosystem of Sundarbans, India: biodiversity, ecology, threats and conservation. In: James N Metras (Ed.), Mangroves: ecology, biology and taxonomy, NOVA Publishers, New York, USA, pp. 83-112.

15. Qasim SZ, Sengupta R, Kureishy TW (1988) Pollution of the seas around India. Proc Indian Acad Sci Anim Sci 97(2): 117-131.

16. Chakraborty SK (2010) Coastal environment of Midnapore, West Bengal: Potential threats and management. Jour Coast Env 1(1): 27-40.

17. Chatterjee S, Chakraborty SK (2014) Feeding behaviour and functional role of some selected species of Brachyuran crabs in nutrient cycle of coastal belt of Midnapore (East), West Bengal, India. J Biol Life Sci 5(1): 106-129.

18. Chakraborty SK (2013) Interactions of environmental variables determining the biodiversity of coastal mangrove ecosystem of West Bengal, India. Ecoscan Spec Issue 3: 251-265.

19. Samanta S, Choudhury A, Chakraborty SK (2014) Morpho-micro anatomical study of Lingula anatina Lamarck, 1801 from West BengalOdisha coast, India. J Mar Biol Assoc India 56(2): 26-33.

20. Samanta S, Choudhury A, Chakraborty SK (2015) Fatty acid fractions of phospholipids in an inarticulate brachiopod fauna inhabiting in West Bengal- Odisha coast, India. Eur J Pharm Med Res 2(3): 620-633.

21. Samanta S, Das TK, Choudhury A, Chakraborty SK (2014) Lipid and fatty acid fractions in Lingula anatina (Brachiopoda): an intertidal benthic fauna in the West Bengal-Orissa coast, India. Journal of coastal life medicine 2(5): 382-388.

22. Samanta S, Choudhury A, Chakraborty SK (2015) Eco-biology of a precambrian intertidal benthic brachiopod, Lingula anatina from the confluence of Subarnarekha estuary with Bay of Bengal, India. J Mar Biol Assoc India 57(1): 41-46

23. Parrish CC (2013) Lipids in marine ecosystem. Department of Ocean Sciences, Memorial University of Newfoundland, St. John's NI, Canada AIC5S7 ISRN Oceanography pp. 1-16.

24. Ghorai S, Samanta S, Chakraborty (2015) Biotransformation of fatty acids by Cerebratulus sp. A study from the eastern coast of India. Elixir Appl Zoology 87: 35561-35564.

25. Das TK, Samanta S, Chatterjee S, Ghosh A, Chakraborty SK, et al. (2014) Pharmacologically active alpha-linoleic acid (ALA, 18:3omega3), the primary precursor molecule for -omega 3 series of polyunsaturated fatty acid (PUFA) from mangrove ecosystem. International Journal of Life Sci Pharma Res 4(2): 34-41.

26. Das Tk, Samanta S, Chakraborty S K (2014b) Pharmacologically active fatty acids of fiddler crab Uca acuta acuta (Simpson). International J of Life Sci Pharma Res. 4(2): 21-27.

27. Bligh EG, Dyer WJ (1959) A rapid method of total lipid extraction and purification. Can J Biochem Physiol 37(8): 911-917.

28. Ackman RG (1989) Fatty acids. In: Ackman RG (Ed.), Marine biogenic lipids. fats and oils. Volume 2, CRC Press, USA, pp. 145-178.
29. Ghosh A, Misra S, Dutta AK, Choudhury A (1985) Pentacyclc triterpenoids and sterols from seven species of mangrove. Phytochemistry 24: 17251727.

30. Gurr M I, Harwood J L, Frayn K N (2002) Lipid biochemistry. In: Gurr MI, Harwood JL, Frayn KN (Eds.), Lipid biochemistry. an introduction( $5^{\text {th }}$ edn), Blackwell Science, Oxford, USA, pp. 1-424.

31. Vance DE, Vance JE (2008) Biochemistry of lipids, lipoproteins, and membranes. In: Vance DE, Vance JE (Eds.), Biochemistry of lipids, lipoproteins, and membranes. ( $5^{\text {th }}$ edn), Elsevier Amsterdam, pp. 1-334.

32. Christie WW, Han X (2010) Lipid Analysis-Isolation, Separation, Identification and Lipidomic Analysis ( $4^{\text {th }}$ edn), Oily Press, Elsevier, pp. 1- 466.

33. Prato E, Danieli A, Maffia M, Biandolino F (2012) Lipid contents and fatty acid compositions of Idotea baltica and Sphaeroma serratum (Crustacea: Isopoda) as indicators of food sources. Zool Stud 51(1): 38-50.

34. Moreno V, de Moreno JE, Brenner RR (1979) Biosynthesis of unsaturated fatty acids in diatom Phaeodactylum tricornutum Lipids 14(1): 15-19.

35. Sargent JR, Lee RF, Nevenzel JC (1976) Marine waxes. In: Kolattukudy PE (Eds.), Chemisrry and biochemistry of natural waxes. Amsterdam: Elsevier, pp. 50-91.

36. Alikunhi NM, Narayanamsamy R, Kandasamy K (2010) Fatty acids in an estuarine mangrove ecosystem. Rev Biol Trop 58(2): 577-587.

37. Gunstone FD (2002) Vegetable oils in food technology: composition, properties and uses. Hoboken: Wiley-Blackwell, USA, pp. 1-342.

38. SanGiovanni JP, Chew EY (2005) The role of omega-3 polyunsaturated fatty acids in health and disease of the retina. Prog Retin Eye Res 24(1): 87-138.

39. Kapoor R, Patil UK (2011) Mini review importance and production of omega-3 fatty acids from natural sources. Int Food Res J 18: 493-499.

40. Serhen C N, Chiang N, Van Dyke TE (2008) Resolving inflammation: dual anti-inflammatory and pro-resolution lipid mediators. Nat Rev Immunol 8(5): 349-361.

41. Auel H, Harjes M, da Rocha R, Stübing D, Hagen W, et al. (2002) Lipid biomarkers indicate different ecological niches and trophic relationships of the Arctic hyperiid amphipods Themisto abyssorum \& T. libellula. Polar Biology 25(5): 374-383.

42. Emig CC (1997) Biogeography of the inarticulated brachiopods. In: Kaesler RL (Ed.), Treatise on invertebrate paleontology, Part $\mathrm{H}$, Brachiopoda, USA, vol 1: 497-450.

43. Misra S, Choudhury A, Pal PK, Ghosh A (1986) Effect on the leaf lipids of three species of man-grove of periodic submergence in tidal water. Phytochemistry 25(5): 1083-1087.

44. Grimes B, Huish M, Kerby J (1989) Species profiles: life histories and of Uca longsignalis \& Uca minax , Mar Sci 70(3): 505-517.

45. Heald EJ, Odum WE (1970) The contribution of mangrove swamps to Florida fisheries. Proc Gulf Carribian Fish Inst 22: 130-135

46. Banerjee D, Pal D, Patra TK (1997) Lipids and fatty acids of air breathing fish Boleophthalmus boddaerti. Food Chemistry 60(3): 303-309.

47. Barlocher F, Corkum M (2003) Nutrient enrichment overwhelms diversity effects in leaf decomposition by stream fungi. Oikos 101(2): 247-252.

48. Prachi S, Shenai T, Desai MN, Jagtap TG (2012) Ecological observation and GC-MS analysis of methanolic extract of Saccoglossas Elysia Bangtawaensis ( Swennen). The Bioscan 7(3): 457-461.

49. Pacey AA, Bentley M G (1992) The fatty acid 8,11,14-eicosatrienoic acid induces spawning in the male lugworm Arenicola marina. J Exp Biol 173: 165-179.

50. Kirubakaran P, Kothapalli R, Dhanachandra SKH (2011) Silico studies 
on marine actinomy- cetes as potential inhibitors for Glioblastoma multiforme Bioinformation 6: 100-106.

51. Avato P, Pesante MA, Fanizzi FP, Santos CA (2003) Seed oil composition of Paullinia cupana var. Sorbilis (Mart.) Ducke. Lipids 38(7): 773-780.

52. Dalsgaard J, St John M, Kattner G, Müller-Navarra D, Hagen W, et al (2003) Fatty acid trophic markers in the pelagic marine environment. Adv Mar Biol 46: 225-340.

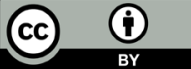

Creative Commons Attribution 4.0

International License

For possible submission use the below is the URL
53. Kelly JR, Scheibling RE (2012) Fatty acids as dietary tracers in benthic food webs. Marine Ecology Progress Series 446: 1-22.

54. Loreau M, Naeem S, Inchausti P, Bengts- son J, Grime JP, et al. (2001) Ecology- biodiversity and ecosystem functioning: current knowledge and future challenges. Science 294(5543): 804-88.

55. Vanni MJ , Layne CD (1997) Nutrient recycling and herbivory as mechanisms in the "top-down" effects of fish on phytoplankton in lakes. Ecology 78(1): 21-41.

Your subsequent submission with Crimson Publishers will attain the below benefits

- High-level peer review and editorial services

- Freely accessible online immediately upon publication

- Authors retain the copyright to their work

- Licensing it under a Creative Commons license

- Visibility through different online platforms

- Global attainment for your research

- Article availability in different formats (Pdf, E-pub, Full Text)

- Endless customer service

- Reasonable Membership services

- Reprints availability upon request

- One step article tracking system 